\title{
EDITORIAL
}

\section{World Federation of Societies of ANaesthesiologists}

The Wortd Federation of Soctettes, of ANAEsthestologists officially came into being on the 9th of September, 1955, in the closing moments of the World Congress of Anaesthesiologists at Schevenigen, in Holland. At that time the delegates of twenty-seven national societes of Anaesthesiologists met in the first Assembly of the World Federation of Societies of Anaesthesiologists; the Assembly formally adopted the Constitution and By-Laws of the Federation, elected officers and an Executive Committee, and applied for incorporation under the laws of The Netherlands.

The final embodiment of the Federation was the first fruit of an idea born at the time of the International Congress of Anaesthesiologists in Paris in 1951, and the culmination of the labours of four years by the Interim Committee set up at the Paris meeting under the chairmanship of Dr. Harold Griffith of Montreal, and with Dr A. Goldblatt of Brussels as its able Secretary. During the week preceding the inaugural Assembly meeting the delegates of the member societies met on several occasions to discuss the Constitution and By-Laws, and the fact that only minor adjustments were made in the ongmal drafts reflects great credit on the work of the Interim Committee.

The object of the World Federation is to make available the highest standard of anaesthesia for all the peoples of the world. In order to fulfil this object, the Constitution sets out these functions for the Federation:

1. To assist and encourage the formation of national societies of anaesthesiologists.

2. To promote the dissemination of scientific information.

3. To recommend desirable standards of training for anaesthesiologists.

4. To provide information regarding opportunities for postgradiate training and research.

5. To encourage research into all aspects of anaesthesiologists.

6. To encourage the establishment of safety measures including the standardization of equipment.

7. To advise, upon request, national and international organizations.

It would seem to us that, aside from activity durected at providing training of a high standard for all who desire it, one of the most important ways of exercising these functions will be in the organization of World Congresses of the type recently held in Holland. The personal exchange of ideas and knowledge at such meetings between anaesthesiologists from all parts of the world must have an impact on the future of anaesthesiology which is only likely to be equalled by that of the mutual respect and friendship between men and women of all nations which are engendered by the personal contact and free discussion made possible by such a Congress. 
World Congress of ANAESTHESIOLOGISTS, 1955

No matter what great meetings of anaesthetists the future may bring, the World Congress of Anaesthesiologists held at Schevenizen in Holland in September, 1955, will remain a high point in the professiona life of every participant. The credit for the outstanding success of this meeting must go to the members of the Netherlands Society of Anaesthesiologists, and especially to Dr. Ritsema van Eck, the Chairman of the organizing committee; to Dr. M. Mauve, President of the Netherlands Society of Anaesthesiologists and Secretary-Treasurer of the Congress; and to Mr. Fentener van Vlissingen, the Manager of the Congress. All who have had the responsibility of organizing any sort of medical meeting will have recognized the superb organization of the Dutch Congress, and will have realized, too, that this could not have been possible without the working cooperation of many members of the Netherlands Society whose part in the great success remains unknown to their guests. A very special accolade is deserved by the wives of our Dutch colleagues, who gave so much time and energy to organizing and guiding the tours and parties designed to entertain our wives and guests, which also provided education in geography and history when we tired a little of being educated in anaesthesiology. 


\section{EDITORIAL}

\section{La Fédération Mondiale des Anesthésistes}

La FÉdÉration Monjiale des Sociétés d'ANEsthésistes fut créée officiellement le 9 septembre 1955 à la fin du Congrès Mondial des Anesthésistes à Schevenigen, en Hollande, quand les délégués de 27 sociétés nationales réunis poư la première assemblie de la Fédération Mondiale des Sociétés d'Anesthésistes adoptèrent formellement la constitution et les réglements de la Fédération, élurent des officiers et un comité exécutif et demandèrent leur incorporation selon la loi hollandaise.

L'organisation définitive de cette fédération fut le premier résultat d'une idée qui vit le jour lors du Congrès International des Anesthésistes à Paris en 1951 et le fruit de quatre années de travail du comité intérimaire nommé à Paris sous la présidence du Dr Harold Griffth de Montréal et avec le Dr A. Coldblatt comme son actif sécrétaire. Durant la semaine qui précèda l'assemblée inaugurale les délégués des sociétés membres se réunirent à plusieurs occasions pour discuter de la constitution et des réglements et le fait que seulement des changements mineurs furent apportés aux projets origmaux démontre la valeur du travail du comité intérimaire.

Le but de la Fédération Mondiale est d'apporter le plus haut standard de science anesthésique à tous les peuples du monde. Dans cette intention, la constitution détermine les fonctions survantes à la Fédération:

1. Assister et encourager la formation de sociétés nationales d'anesthésie.

2. Promouvoir la diffusion de l'information scientifique.

3. Recommander des standards désirables dans l'entraînement des anesthésistes.

4. Fournir des renseignements au sujêt des postes disponibles pour entraînement ou recherche.

5. Encourager la recherche dans tous les sujets reliés à l'anesthésie.

6. Promouvoir l'établissement de mesures de sécurité irıcluant la standarisation de l'équipement.

7. Conseller sur demande, les organisations nationales et internationales.

Il nous semble, qu'en plus de l'effort pour fournir un entraînement supérieur à tout ceux qui le désirent, l'une des plus importantes manières d'exercer ces fonctions sera dans l'organisation de Congrès mondiaux semblables à celui récemment tenu en Hollande. L'opportunité qui fournit de semblables réunions d'échanger des idées et des connaissances entre anesthésistes de toutes les parties du monde devrait faire sa marque sur le futur de l'anesthésie et également promouvoir le respect mutuel et l'amitié entre hommes et femmes de toutes les nations par le contact personnel et la discussion libre rendus possibles par un tel Congrès.

\section{Le Congrìs Mondial des Anesthésistes, 1955}

Quelque soit l'importance des futurs congrès d'anesthésie, le Congrès Mondial tenu à Schevenigen en Hollande en septembre 1955 restera une étape re- 
marquable dans la vie professionnelle des participants. Le mérite du succès exceptionnel de ce congrès doit être donné aux membres de la Société des Anesthésistes hollandais et spécialement au Dr Ritsema van Eck, le président du comité d'organisation; au $\operatorname{Dr}$ M. Mauve, président de la Société hollandaise d'anesthésie et sécrétaire-trésorier du congrès, à Mr. Fentener van Vlissingen, l'organisateur du congrès. Tout ceux qui ont déjà eu la responsibilité d'organiser des réunions médicales, auront admiré l'organisation superbe du Congrès hollandais et auront réalisé aussi que ceci n'a pu être possible qu'avec la coopération active de nombreux membres de la société hollandaise dont la contribution à ce grand succès demeure inconnue à leurs invités. Les épouses de nos collègues hollandais méritent les plus vifs remerciements pour avoir donné tant de temps et d'énergie à organıser visites et réceptions pour nos épouses. Ces visites et réceptions nous ont fourni aussi la possibilité d'augmenter nos connaissances en histoire et géographie quand nous étions un peu fatigués de nous instruire en anesthésie. 